\title{
Association of Epstein-Barr virus infection and breast carcinoma
}

Mohamad Nidal Khabaz

Department of Pathology, Faculty of Medicine, King Abdulaziz University, Jeddah, Saudi Arabia

Submitted: 24 April 2012

Accepted: 23 October 2012

Arch Med Sci 2013; 9, 4: 745-751

DOI: 10.5114/aoms.2013.37274

Copyright $\odot 2013$ Termedia \& Banach

\section{Abstract}

Introduction: A controversy regarding the association of Epstein-Barr virus (EBV) with breast carcinomas has recently been reported in the literature. The present study was carried out in an attempt to determine whether there is a relationship between latent infection with EBV and breast carcinomas in Jordanian females.

Material and methods: Extraction of DNA from the archive samples of breast carcinoma cases embedded in paraffin wax was performed and the extracted DNA was subjected to polymerase chain reaction amplification to detect the EBV genome using four sets of primers for EBER 2, BNLF-1, EBNA 2, and Gp220. Immunohistochemistry study was performed on sections of $4 \mu \mathrm{m}$ which were cut from paraffin blocks of tumor and control groups. Monoclonal antibody against EBNA-1 was applied to all slides to identify the EBV-infected tumor cells. Detection was performed using the Dako envision dual link system.

Results: DNA was successfully extracted from 92 paraffin embedded samples of breast carcinoma patients, and from 49 normal samples. The extracted DNA was confirmed by using glyceraldehyde-3-phosphate-dehydrogenase (GAPDH) primers. Twenty-four out of 92 breast carcinoma specimens was found to be infected with EBV as compared to 3 out of 49 control group specimens, which represented a statistically significant difference ( $p$-value using $\chi^{2}=0.008$ ). Immunohistochemically, 24 (26\%) of the 92 studied samples were found to be positive, showing EBNA-1 granular nuclear staining in tumor epithelial cells.

Conclusions: These findings suggest an association between EBV infection and breast carcinoma development.

Key words: Epstein-Barr virus, breast carcinoma, polymerase chain reaction.

\section{Introduction}

Epstein-Barr virus (EBV) is one of eight members of the human herpes virus family (Herpesviridae) and is ubiquitous among human populations. About $90-95 \%$ of people are infected, usually in childhood or early adolescence, with different manifestations [1]. However, it is also found in neoplastic diseases, associated with highly aggressive tumor progression and poor patient survival. The establishment of a correlation between tumor development and viral infection dates back to the beginning of the $20^{\text {th }}$ century [2], even though only over the past 15 years several studies have raised the possibility that EBV may also be involved in the pathogenesis of breast carcinoma, the most common carcinoma in females [3]. Early studies addressing this issue focused on medullary carcinomas since these
Corresponding author: Dr. Mohamad Nidal Khabaz Department of Pathology Faculty of Medicine King Abdulaziz University (Rabigh Branch)

P.O. Box: 80205 Jeddah 21589, Saudi Arabia Phone: 966-2-6400000 ext 20078 Mobile: 00966-563998879 E-mail: mnkhabaz@kau.edu.sa, nkhabaz@yahoo.co.uk 
are morphologically similar to nasopharyngeal carcinoma. However, these studies consistently failed to detect EBV using various techniques $[4,5]$. Nonetheless, until 1995, the association between viral infection and breast carcinoma development was not supported by any study until Labrecque et al. [6] detected EBV in epithelial cells of breast carcinomas. Since then, EBV infection as an etiological agent of breast carcinoma has remained somehow controversial and may vary from population to population [3, 6-12]. Although the WHO International Agency for Research on Carcinoma (IARC) has classified EBV among group I carcinogens which are agents that definitely cause neoplasm in humans, proof beyond a reasonable doubt that EBV infection plays a role in the development of breast carcinomas requires substantial additional evidence that can only be obtained through further research.

The precise role that this virus plays in tumorigenesis is still not clear; however, understanding this association is potentially important to identify women at risk for this type of breast carcinoma, who might benefit from use of the virus as a tumor burden marker that could potentially assist in early diagnosis or in measurement of post-therapy residual disease.

This is the first study to investigate the association between EBV infection and the development of breast carcinoma in Jordanian females. In 2007, breast carcinoma ranked $1^{\text {st }}$ among carcinomas in females and it accounted for $35.8 \%$ of all female carcinomas in Jordan. The median age at diagnosis of breast carcinoma in females was 52.2 years. The crude incidence rate for female breast carcinoma was 29.5 per 100,000 female population, compared to 27.6 per 100,000 in 2006 . The highest age-specific incidence rate (213.3) per 100,000 was found in the age group 75-79 years. The age standardized rate (ASR) for female breast carcinoma was 48.9 per 100,000 female population. Histopathological distribution of female breast carcinomas showed that $77.4 \%$ were infiltrating ductal carcinoma, 7.1\% lobular carcinoma, $1.8 \%$ were mixed ductal and lob- ular carcinoma, 5.6\% carcinoma NOS (not otherwise specified), and the rest showed other types of morphology [13].

This study used the polymerase chain reaction (PCR) and immunohistochemistry techniques and paraffin embedded tissue of histopathologically diagnosed breast carcinomas to assay for the presence of EBV DNA and its protein product in these tissue samples.

\section{Material and methods}

\section{Samples}

This study includes 92 samples of paraffin embedded tissue blocks of female breast carcinoma. All samples and the clinical data including age group, type of carcinoma, size and grade of carcinoma were collected from the medical records and the Pathology Department at Jordan University of Science and Technology. All samples were stored at room temperature.

The median age of the patients was 45.88 years (range, 20 to 75 years). Node involvement was detected in $34 \%$ of the cases. The tumor size was $<1 \mathrm{~cm}$ in diameter in $6 \%$ of the cases, $>1$ and $<3 \mathrm{~cm}$ in $39 \%$ of cases, and $>3 \mathrm{~cm}$ in $55 \%$ of cases. Tumor type was ductal in $88.1 \%$ of the cases, lobular in $7.6 \%$ of the cases, and of other types in $4.3 \%$ of the cases. The distribution of histoprognostic grading was $10.9 \%$ for grade I, $34.8 \%$ for grade II, and $50 \%$ for grade III (Table I). On the other hand, 49 case controls, from paraffin embedded breast tissues of noncarcinomatous conditions (including 23 fibroadenomas, 8 fibrocystic changes, 4 duct ectasias, 4 sclerosing adenosis, 4 hyperplasias, 3 tubular adenomas and 3 intraductal papillomas), were treated in the same conditions. The median age of the benign cases was 37.6 years (range: 20 to 56 years). The size of benign lesions ranged from $1 \mathrm{~cm}$ to $2 \mathrm{~cm}$ in diameter, which was obtained by open surgical biopsy due to the fear of hidden microscopic cancer.

Table I. Breast cancer sample information and PCR results

\begin{tabular}{|c|c|c|c|c|c|c|c|c|c|c|c|c|}
\hline \multirow{2}{*}{$\begin{array}{l}\text { Type of } \\
\text { breast } \\
\text { cancer }\end{array}$} & \multirow[t]{2}{*}{ Grade } & \multirow{2}{*}{$\begin{array}{c}\text { Total } \\
\text { number } \\
\text { of cases }\end{array}$} & \multirow{2}{*}{$\begin{array}{l}\text { Range } \\
\text { of ages }\end{array}$} & \multirow{2}{*}{$\begin{array}{c}\text { Mean } \\
\text { age }\end{array}$} & \multirow{2}{*}{$\begin{array}{c}\text { Range } \\
\text { of sizes } \\
{[\mathrm{cm}]}\end{array}$} & \multicolumn{6}{|c|}{ PCR Positive cases } & \multirow{2}{*}{$\begin{array}{c}\text { IHC } \\
\text { Positive } \\
\text { cases }\end{array}$} \\
\hline & & & & & & GAPDH & EBER2 & EBNA2 & $\begin{array}{l}\text { BNLF1 } \\
\text { (LMP) }\end{array}$ & GP220 & EBV & \\
\hline \multirow[t]{3}{*}{ IDC } & I & 10 & $29-64$ & 45.88 & $0.1-5$ & 10 & 2 & 2 & 2 & 2 & 2 & 2 \\
\hline & II & 32 & $23-75$ & & $1.5-7.5$ & 32 & 9 & 9 & 10 & 9 & 9 & 9 \\
\hline & III & 39 & $20-75$ & & $2.1-11$ & 39 & 10 & 10 & 13 & 10 & 10 & 10 \\
\hline Lobular & III & 7 & $34-70$ & & $1-20$ & 7 & 3 & 3 & 3 & 3 & 3 & 3 \\
\hline Medullary & & 3 & $27-50$ & & $0.5-4$ & 3 & & & & & & \\
\hline Mucinous & & 1 & 66 & & 2 & 1 & & & & & & \\
\hline
\end{tabular}
ed RNA, IHC - immunohistochemistry 


\section{Immunohistochemistry (IHC)}

Sections of $4 \mu \mathrm{m}$ were cut from paraffin blocks (from representative tumor samples with exclusion of lymph nodes and necrotic sections of the primary tumor and from specimens of the control group). All paraffin sections were taken on coated slides and were dewaxed in xylene, rehydrated through series of graded alcohol, placed in $10 \mathrm{mM}$ citrate buffer ( $\mathrm{pH}$ 6.0) and submitted to heat retrieval for $6 \mathrm{~min}$. After heating, the slides were allowed to cool to room temperature and washed with phosphate buffered saline (PBS). Endogenous peroxidase activity was blocked with 3\% hydrogen peroxide in methanol for $5 \mathrm{~min}$. Serum-free protein block (Dako, Denmark) was used for 5 min in order to block nonspecific immunoreaction. Monoclonal antibody EBNA-1 (Dako, Denmark), was diluted $1: 50$ in Dako antibody diluent and was applied to all slides for $30 \mathrm{~min}$ at room temperature, to identify the EBV-infected tumor cells. Detection was performed using the Dako envision dual link system (Dako, Denmark) according to the manufacturer's instructions. After that, slides were visualized using Dako liquid DAB (Dako, Denmark). Mayer's hematoxylin was applied as a counterstain.

The positive control for EBV infection was a slide containing a Hodgkin lymphoma specimen known to harbor the virus run simultaneously with the samples. As a negative control, the primary antibodies were omitted. In addition, the tumor tissue was compared with the adjacent normal tissue as available. Tumors were considered to be positive for EBNA-1 if more than 1\% of the neoplastic cells displayed distinct brown nuclear staining.

\section{DNA extraction}

Paraffin-embedded sections of $10 \mu \mathrm{m}$ thickness belonging to all cases (carcinoma and controls) were subjected to polymerase chain reaction (PCR) in order to detect the presence of EBV genome in these tissues. Sectioning by a specific microtome was performed for all samples by using a specific lancet for each sample; each lancet was treated with xylene, $70 \%$ ethanol, and autoclaved. Between sample sectioning, each time the microtome was treated with xylene and $70 \%$ ethanol four times. Sectioning of the samples was completed at different times to minimize the probability of contamination. DNA from paraffin embedded tissue blocks was extracted with an EXTRAffin ${ }^{\circledR}$ kit (Nanogen Advanced Diagnostics S.r.L., Buttigliera Alta, ITALY) according to the manufacturer's instructions. The extraction product was stored at $-20^{\circ} \mathrm{C}$.

\section{Selection of primers}

All of the primers were selected from the literature $[14,15]$. A specific primer for DNA extraction validity was selected to detect the glyceraldehyde3-phosphate dehydrogenase gene (GAPDH). Four primers (EBER 2, BNLF-1, EBNA 2, Gp220) (Operon Technologies, San Pablo, CA) for certain regions of the EBV genome were selected to be the tool for amplification of EBV DNA (Table II).

\section{PCR amplification of extracted DNA}

Crude DNA extract (about $5 \mu \mathrm{l}$ ) was incubated in a reaction mixture that contained DNA-free, RNAfree, DNase-free, RNase-free (1X) PCR buffer, $3 \mathrm{mM}$ $\mathrm{MgCl}_{2}, 0.5 \mu$ l of $5 \mathrm{U} / \mathrm{ml}$ Taq polymerase, $0.4 \mathrm{mM}$ of each dNTP (Promega, Madison, USA), and $0.5 \mu \mathrm{M}$ of each primer. The presence of human genome was confirmed by the amplification of a specific region that represents the GAPDH gene. The PCR mixture of each sample was denatured at $96^{\circ} \mathrm{C}$ for $2 \mathrm{~min}$, then 39 cycles of amplification at $96^{\circ} \mathrm{C}$ for $30 \mathrm{~s}, 55^{\circ} \mathrm{C}$ for $1 \mathrm{~min}$, and $72^{\circ} \mathrm{C}$ for $2 \mathrm{~min}$ for each cycle. At the final step, amplification at $72^{\circ} \mathrm{C}$ for $10 \mathrm{~min}$ was executed. On the other hand, amplifi-

Table II. Primer used for DNA amplification of EBV genome

\begin{tabular}{|c|c|c|c|c|c|c|}
\hline No. & Targ & t genes & Sequences ( $5^{\prime}$ to $\left.3^{\prime}\right)$ & $\begin{array}{c}\text { Region of } \\
\text { amplification }\end{array}$ & $\begin{array}{c}\text { Annealing temp. } \\
{\left[{ }^{\circ} \mathrm{C}\right]}\end{array}$ & $\begin{array}{l}\text { Expected product } \\
{[\mathrm{bp}]}\end{array}$ \\
\hline \multirow[t]{2}{*}{1} & GAPDH & GAPDH $3 S$ & GGCCTCCAAGGAGTAAGACC & & 55 & 157 \\
\hline & & GAPDH 3AS & ССССTCTTCAAGGGGTCTAC & & & \\
\hline \multirow[t]{2}{*}{2} & EBER 2 & EBER-2S & CCCTAGTGGTTTCGGACACA & $6969-6988$ & 60 & 108 \\
\hline & & EBER-2AS1 & ACTTGCAAATGCTCTAGGCG & $7075-7056$ & & \\
\hline \multirow[t]{2}{*}{3} & EBNA 2 & E2 up & AGGCTGCCCACCCTGAGGAT & 48170-48189 & 58 & 170 or 189 \\
\hline & & E2 low & GCCACCTGGCAGCCCTAAAG & 48339-48320 & & \\
\hline \multirow[t]{2}{*}{4} & BNLF-1 & LMP2CS & CTAGCGACTCTGCTGGAAAT & 168373-168392 & 55 & 307 or 337 \\
\hline & & LMP2CAS & GAGTGTGTGCCAGTTAAGGT & $168075-168056$ & & \\
\hline \multirow[t]{2}{*}{5} & Gp220 & Primer 1 & GGCTGGTGTCACCTGTGTTA & BamHIL region & 55 & 239 \\
\hline & & Primer 2 & CCTTAGGAGGAACAAGTCCC & & & \\
\hline
\end{tabular}


cation of the EBV genome was completed under the same conditions of the PCR mixture, but with a different annealing temperature for each primer. The optimum annealing temperature for $E B E R$, EBNA, BNLF1 and gp220 primers was $60^{\circ} \mathrm{C}, 58^{\circ} \mathrm{C}$, $55^{\circ} \mathrm{C}, 55^{\circ} \mathrm{C}$ respectively [15-17].

The DNA-positive control for EBV was derived from Hodgkin lymphoma known to harbor the virus and nuclease-free distilled water replacing DNA was used as a DNA-negative control. The PCR products were detected by agarose electrophoresis, at a final concentration of $1.5 \%$, containing $5 \mu \mathrm{g} / \mathrm{ml}$ ethidium bromide. The DNA bands were visualized under UV illumination and documented by photography.

The sample was considered EBV positive if it was successfully amplified by four sets of primers.

\section{Statistical analysis}

All statistical analyses were performed using EpiInfo version 6 . The $\chi^{2}$ test was used to compare qualitative variables. Values of $p \leq 0.05$ was considered a significant difference.

\section{Results}

\section{Immunohistochemistry}

EBV-infected cells and viral expression were demonstrated by identification of the viral protein

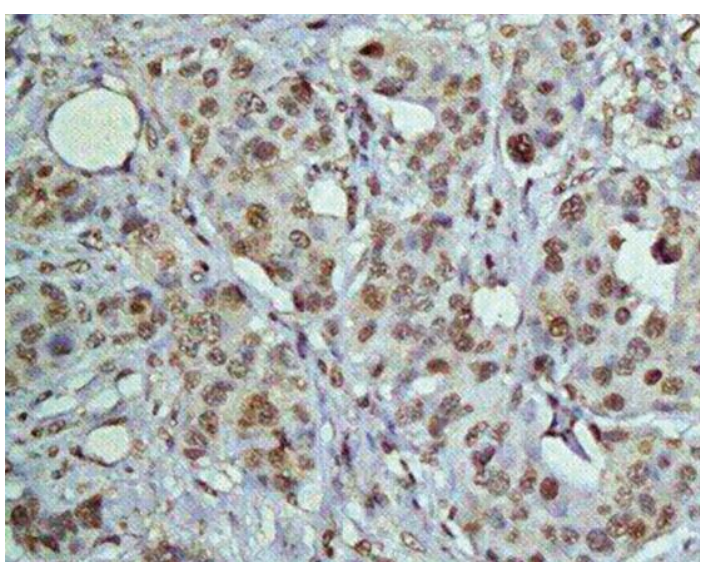

Figure 1. Immunohistochemistry study using monoclonal antibody against EBNA-1 antigen and Mayer's hematoxylin as counterstain revealed EBNA-1 gran ular nuclear staining in tumor epithelial cells. Magnification $400 x$
EBNA-1, which is essential for maintenance of the viral episome and for its replication. Twenty-four (26\%) of the 92 studied samples were found to be positive, showing EBNA-1 granular nuclear staining in tumor epithelial cells (Figure 1). The proportion of EBNA-1-positive tumor cells varies from one tumor to another, ranging from $5 \%$ to $50 \%$. Ductal and lobular variants of carcinoma were similarly involved. No EBNA-1 granular nuclear staining was found in lymphoplasmacytic cells that infiltrate the stroma. We failed to detect EBNA-1 expression in noncarcinomatous conditions of breast tissue samples. In the overall studied female population, no statistically significant association was observed between EBNA-1 expression and worse clinical and pathological features.

\section{DNA extraction and detection of human EBV genomes}

DNA was successfully extracted from paraffin embedded tissues from both breast carcinoma and controls. GAPDH primers were used to detect the presence of human DNA in the cell lysate for both breast carcinoma and controls. Human GAPDH DNA was successfully detected and amplified in all breast carcinoma and control samples with the product size of $157 \mathrm{bp}$ (Table I and Figure 2).

DNA was amplified by PCR with primers covering four regions of the EBV genome: EBER-2 (108 bp), EBNA-2 (170 bp), BNLF1 (307 or 337 bp for BNLF1 according to polymorphism), and gp220 (239 bp). Twenty-four (26\%) out of 92 breast carcinoma samples revealed positive PCR results of the mentioned regions above and EBV genome. Exemplary PCR results are presented in Table I and Figures $3-7$. Three $(6 \%)$ out of 49 noncarcinomatous tissue samples were positive for the presence of EBV genome. The EBNA-1 immunohistochemical detection and PCR analysis results are in harmony with each other.

\section{Statistical analysis}

Our results showed a significant difference between breast carcinoma and control groups and a considerable association between EBV infection and breast carcinoma. The odds ratio was 5.4 $(95 \% \mathrm{Cl}=1.43,24.04)$ and the statistically calcu-

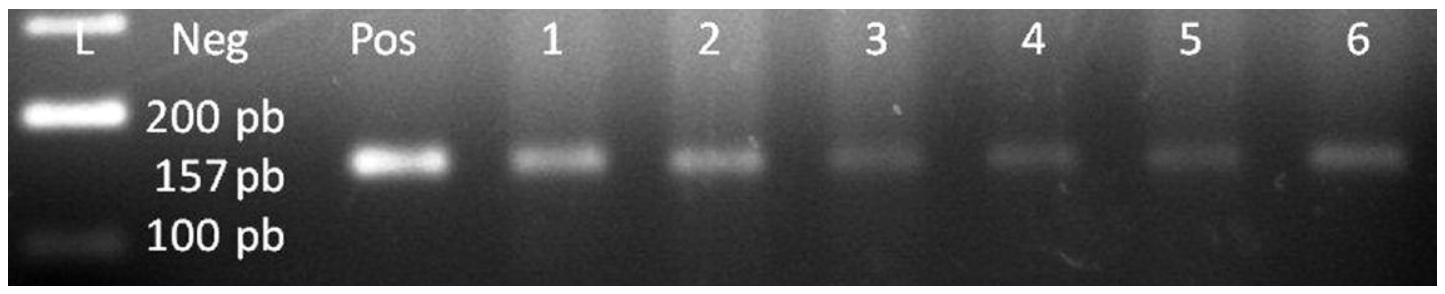

Figure 2. GAPDH, lane 1100 bp DNA Ladder, lane 2 negative control, lane 3 positive control, lanes 4-9 positive patient samples 


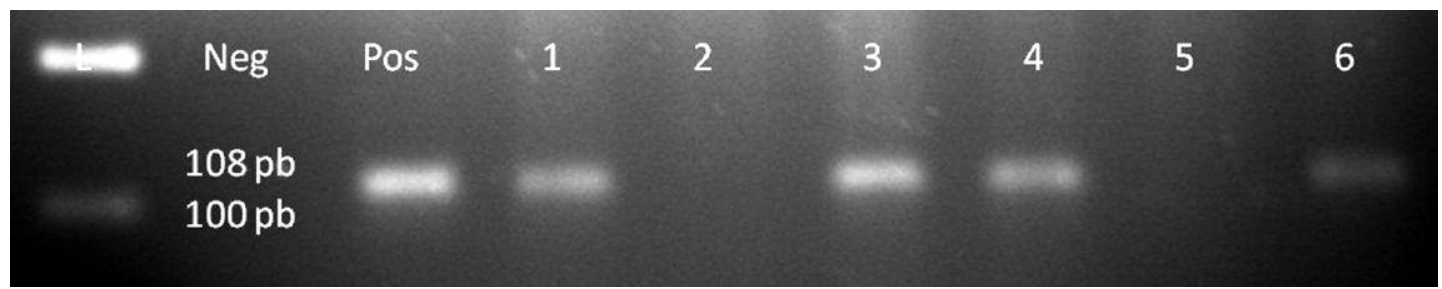

Figure 3. EBER2 gene of EBV genome, lane 1100 bp DNA Ladder, lane 2 negative control, lane 3 positive control, lanes 4-9 patient samples, samples 1, 3, 4, 6 are positive for EBER2

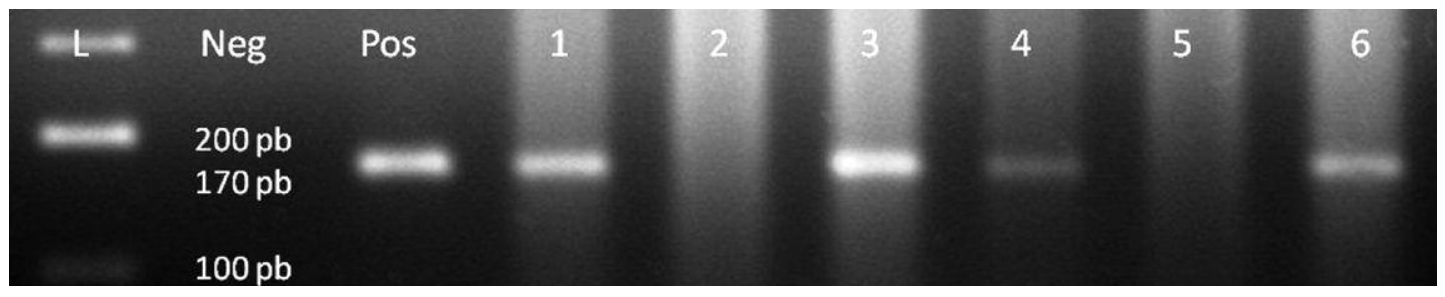

Figure 4. EBNA2 gene of EBV genome, lane 1100 bp DNA Ladder, lane 2 negative control, lane 3 positive control, lanes 4-9 patient samples, samples 1, 3, 4, 6 are positive for EBNA2

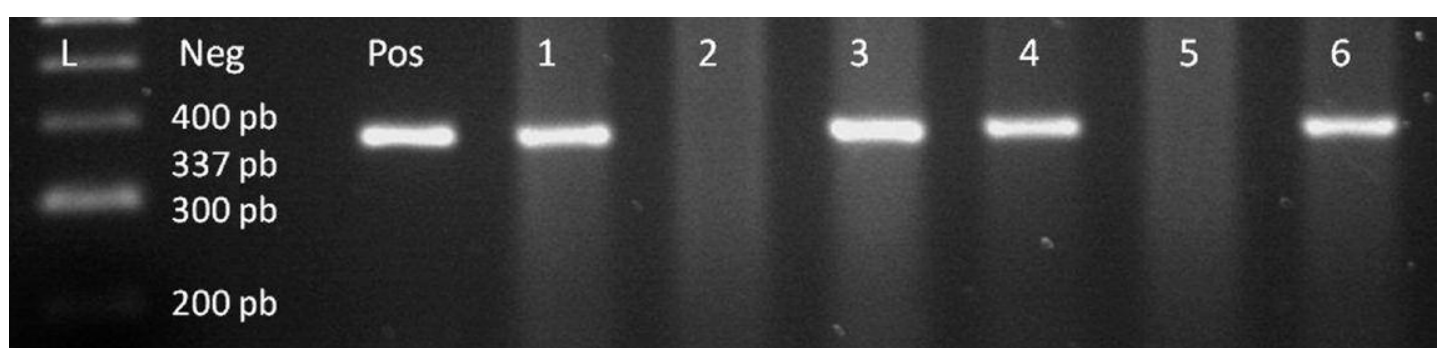

Figure 5. BNLF1 gene of EBV genome, lane 1100 bp DNA Ladder, lane 2 negative control, lane 3 positive control, lanes 4-9 patient samples, samples 1, 3, 4, 6 are positive for BNLF1

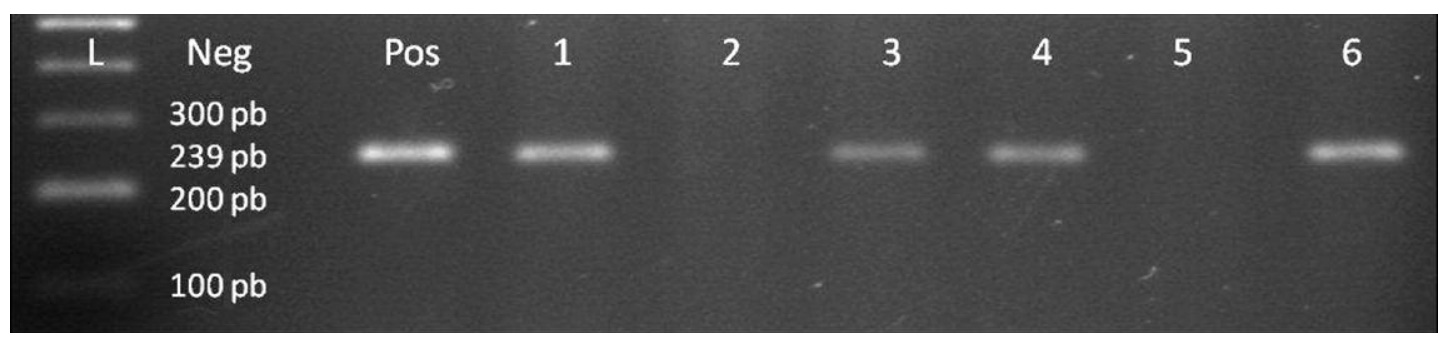

Figure 6. Gp220 gene of EBV genome, lane 1100 bp DNA Ladder, lane 2 negative control, lane 3 positive control, lanes 4-9 patient samples, samples 1, 3, 4, 6 are positive for Gp220

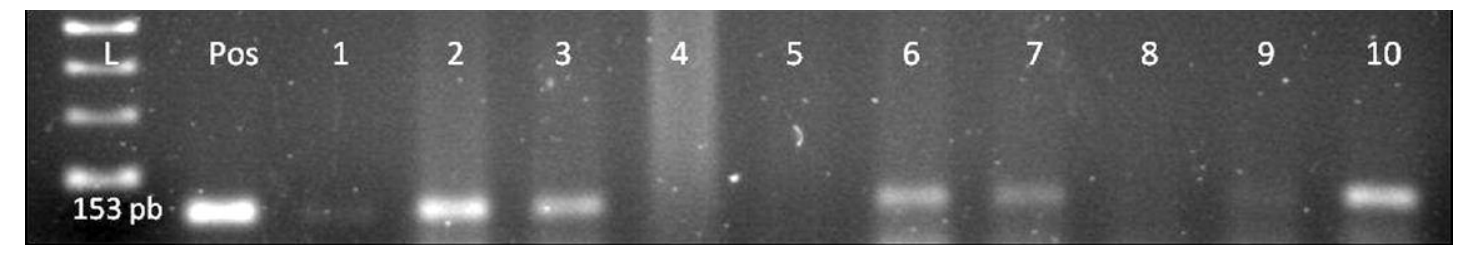

Figure 7. EBV genome, lane 1100 bp DNA Ladder, lane 2 positive control, lanes 1-10 patient samples, samples 2, 3, $6,7,10$ are positive for $E B$ 
Table III. Association of EBV infection and clinical parameters including age, tumor size, tumor grade, and involvement of lymph nodes

\begin{tabular}{|cccc|}
\hline Age group & EBV infection positive & EBV infection negative & 32 \\
\hline$>50$ & 9 & 36 & 51 \\
\hline$<50$ & 15 & 68 & 92 \\
\hline Total & 24 & EBV infection negative & Total \\
\hline Size of the tumor & EBV infection positive & 5 & 5 \\
\hline$<1$ & 0 & 26 & 36 \\
\hline $1-<3$ & 10 & 37 & 51 \\
\hline$>3$ & 14 & 68 & 92 \\
\hline Total & 24 & EBV infection negative & Total \\
\hline Grade & EBV infection positive & 8 & 10 \\
\hline I & 2 & 24 & 33 \\
\hline II & 9 & 36 & 49 \\
\hline III & 13 & 24 & 98 \\
\hline
\end{tabular}

lated $p$-value using $\chi^{2}$ was 0.008 . The cases of breast carcinoma have five-fold more EBV compared with the controls. The odds ratio, when the control group is made the reference group, is statistically significant between the three grades of breast carcinoma. The $p$-value and odds ratio revealed that the difference between the three grades of breast carcinoma is not significant when not comparing with the control group. Moreover, there is no association between the development of breast carcinoma with EBV infection and age, grade, and size of tumor (Table III).

\section{Discussion}

The identification of EBV genome in breast carcinoma and its role as a carcinogen has been constantly debated, over the past decade, despite many studies which well documented the presence of EBV genetic material in up to $51 \%$ of breast tumors [3, 6-12]. This inconsistency is attributable to the failure of some investigators to identify EBV in breast carcinoma [3]. A possible explanation might be the epidemiological variation in EBV infections, such as variance in age at the time of acquiring primary EBV infection, as populations with higher incidence rates of breast carcinoma correspond to those with higher possibility of delayed primary EBV infection [18]. Furthermore, this controversy might be due to diversity in the methodologies used for detecting the virus and different EBVderived proteins or nucleic acids investigated [19].

The present study demonstrated the presence of EBV in $26 \%$ of breast carcinoma samples by immunohistochemistry and PCR amplification. Our results confirm and broaden earlier reports, including the relative proportion of positive cases, $20 \%$ by
Labrecque et al. [6]; $40 \%$ by Luqmani and Shousha [20]; $51 \%$ by Bonnet et al. [14]; $31.8 \%$ by Fina et al. [21]; 35\% by Preciado et al. [9]; $45.2 \%$ by Tsai et al. [22]; and $46 \%$ by Perkins et al. [23]. In addition, they argue against others that failed to detect EBV in breast carcinoma samples [11, 12, 19, 24].

Since the impact of this finding remarkably depends on the localization of the virus, using IHC, EBNA-1 has been revealed in all EBV DNA-positive breast carcinomas. The observed EBNA-1 expression was restricted to tumor epithelial cells and the proportion of EBNA-1-positive tumor cells varied from one tumor to another, ranging from $5 \%$ to $50 \%$. The neighboring normal breast tissues were not labeled and there was no EBNA-1 granular nuclear staining in the lymphocytes infiltrate the tumor stroma. Furthermore, neither EBV DNA nor EBNA-1 was detected in the specimens of the control group except three out of 49 noncarcinomatous tissue samples that were positive for the presence of EBV genome. These results confirm that EBV expression is mostly restricted to tumor epithelial cells and that the cellular source of the PCR EBV DNA was the epithelial tumor cell. The divergence between cases and controls is strongly suggestive of a role for EBV in breast carcinoma. This is supported by claims of several reports which have used breast tissue either from normal women or from various benign diseases or from normal breast tissues adjacent to the tumor as controls; such latter tissues are more likely to carry suspect viruses than normal tissue sourced from normal women. EBV genetic material and/or gene products were rarely identified in control breast tissues and were restricted to tumor epithelial cells [6, 9, 14, 22]. Even when Chu et al. [24] found that there are more infiltrat- 
ing lymphocytes in EBV-positive breast cancer than in EBV-negative tumors (71\% against $27 \%$ ), these infiltrating lymphocytes themselves were EBV negative. The variable distribution of EBNA-1 within EBV-associated breast carcinoma was also recognized by Bonnet et al. [14] and Grinstein et al. [25], who found EBNA-1 by IHC in 5 to $30 \%$ of the tumor cells. The fact that only a fraction of breast carcinoma tumor cells was found to be EBNA-1 positive could reflect low expression or low accessibility of the protein to staining in some cells. Alternatively, the breast carcinomas are highly heterogeneous in terms of genome content and distribution. Consequently, based on these results we can suggest that EBV may play a role in breast cancer oncogenesis but it is unlikely to be a primary etiological agent as EBV is only detected in some breast cancer cells. Instead, EBV mostly acts in concert with other co-factors.

In conclusion, the present results demonstrated EBV infection in a considerable fraction of breast carcinomas in a Jordanian female population. The viral genome was restricted to tumor epithelial cells, and this indicates that EBV may play a role in the development and behavioral alteration of some breast carcinomas. Therefore, further investigations on a larger panel of patients with different tumor grades and variable steroid receptor expression status can be of great value in adding more information as regards the association of EBV with breast carcinoma.

\section{Acknowledgments}

The author is grateful to Dr. Jamil R Alalami, Mohamad Alotoom and Nidal Ganim for excellent technical assistance.

The work was conducted at Jordan University of Science and Technology.

\section{References}

1. Schooley RT. Epstein-Barr virus (infectious mononucleosis). In: Mandell, Douglas and Bennett's principles and practice of infectious diseases. Churchill Livingstone, New York 1995; 1364-77.

2. Rous P, Kidd JG. The carcinogenic effect of a virus upon tarred skin. Science 1936; 468-9.

3. Murray PG. Epstein-Barr virus in breast carcinoma: artifact or etiological agent? J Pathol 2006; 209: 430-5.

4. Lespagnard L, Cochaux P, Larsimont D, Degeyter M, Velu T, Heimann R. Absence of Epstein-Barr virus in medullary carcinoma of the breast as demonstrated by immunophenotyping, in situ hybridization and polymerase chain reaction. Am J Clin Pathol 1995; 103: 449-52.

5. Dadmanesh F, Peterse JL, Sapino A, Fonelli A, Eusebi V. Lymphoepithelioma-like carcinoma of the breast: lack of evidence of Epstein-Barr virus infection. Histopathology 2001; 38: 54-61

6. Labrecque LG, Barnes DM, Fentiman IS, Griffin BE. Epstein-Barr virus in epithelial cell tumors: a breast carcinoma study. Carcinoma Res 2001; 55: 39-45.
7. Fawzy S, Sallam M, Awad NM. Detection of Epstein-Barr virus in breast carcinoma in Egyptian women. Clin Biochem 2008; 41: 486-92.

8. Arbach H, Viglasky V, Lefeu F, et al. Epstein-Barr virus (EBV) genome and expression in breast carcinoma tissue: effect of EBV infection of breast carcinoma cells on resistance to paclitaxel (Taxol). J Virology 2006; 80: 845-53.

9. Preciado MV, Chabay PA, De Matteo EN, et al. EpsteinBarr virus in breast carcinoma in Argentina. Arch Pathol Lab Med 2005; 129: 377-81.

10. Perrigoue JG, den Boon JA, Friedl A, Newton MA, Ahlquist $P$, Sugden B. Lack of association between EBV and breast carcinoma. Carcinoma Epidemiol Biomarkers Prev 2005; 14: 809-14.

11. Herrmann K, Niedobitek G. Lack of evidence for an association of Epstein-Barr virus infection with breast carcinoma. Breast Carcinoma Res 2003; 5: 13-7.

12. Deshpande CG, Badve S, Kidwai N, Longnecker R. Lack of expression of the Epstein-Barr Virus (EBV) gene products, EBERs, EBNA1, LMP1, and LMP2A, in breast carcinoma cells. Lab Invest 2002; 82: 1193-9.

13. Tarawneh M, Nimri O. Ministry of Health, Jordan Carcinoma Registry, Carcinoma Incidence in Jordan, 12th report of the Jordan Carcinoma Registry (http://www.moh.gov.jo/ MOH/Files/Publication/MINISTRYOFHEALTH_1.pdf) (2007).

14. Bonnet $M$, Guinebretiere JM, Kremmer E, et al. detection of Epstein Barr virus in invasive breast carcinomas. J Natl Carcinoma Inst 1999; 91: 1376-81.

15. Araujo I, Foss HD, Bittencourt A, et al. Expression of Epstein Barr virus gene product in Burkitt's lymphoma in northeast Brazil. Blood 1996; 87: 5279-86.

16. Sepp R, Szabo I, Uda H, Sakamoto H. Rapid technique for DNA extraction from routinely processed archival tissue for use in PCR. J Clin Pathol 1994; 47: 318-23.

17. Telenti A, Marshall WF, Smith TF. Detection of Epstein Barr Virus by polymerase chain reaction. J Clin Microbiol 1990; 28: 2187-90.

18. Yasui Y, Potter JD, Stanford JL, et al Breast carcinoma risk and "delayed" primary Epstein-Barr virus infection. Carcinoma Epidemiol Biomarkers Prev 2001; 10: 9-16.

19. Glaser SL, Ambinder R, DiGiuseppe J, Horn-Ross P, Hsu J. Absence of Epstein Barr virus EBER-1 transcripts in epidemiologically diverse group of breast carcinoma. Int J Carcinoma 1998; 75: 555-8.

20. Luqmani Y, Shousha S. Presence of Epstein-Barr virus in breast carcinoma. Int J Oncol 1995; 6: 899-903.

21. Fina F, Romain S, Ouafik LH. Frequency and genome load of Epstein-Barr virus in 509 breast carcinomas from different geographical areas. Br J Carcinoma. 2001; 84: 783-90.

22. Tsai JH, Tsai CH, Cheng MH, Lin SJ, Xu FL, Yang CC. Association of viral factors with non-familial breast carcinoma in Taiwan by comparison with non-carcinomaous, fibroadenoma, and thyroid tumor tissues. J Med Virol 2005; 75: 276-81.

23. Perkins RS, Sahm K, Marando C, et al. Analysis of EpsteinBarr virus reservoirs in paired blood and breast carcinoma primary biopsy specimens by real time PCR. Breast Carcinoma Res 2006; 8: R70.

24. Chu PG, Chang K, Chen Y, Chen W, Weiss L. No significant association of Epstein-Barr virus infection with invasive breast carcinoma. Am J Pathol 2001; 159: 571-8.

25. Grinstein S, Preciado MV, Gattuso P, et al. Demonstration of Epstein-Barr virus in carcinomas of various sites. Carcinoma Res 2002; 62: 4876-8. 